\title{
Preservation of Digital Local Content Among University Libraries in Northeast Nigeria
}

\author{
Abubakar Mohammed ${ }^{1}$, Ali Garba ${ }^{2}$, Zainab Mohammed Abdullahi ${ }^{3}$ \\ ${ }^{1}$ Department of Library and Information Science Modibbo Adama University of Technology \\ Adamawa State, Nigeria \\ amkareto@gmail.com \\ ${ }^{2}$ Kashim Ibrahim Library Ahmadu Bello University (ABU) \\ Zaria. Kaduna State \\ Nigeria \\ karayeunque@gmail.com \\ ${ }^{3}$ Department of Library and Information Science $(\mathrm{PhD})$ \\ Modibbo Adama University of Technology \\ Adamawa State, Nigeria \\ zainabmabdullahi@yahoo.com
}

ABSTRACT: Purpose - The major purpose of this study is to determine the digital local content available and how these digital local content are preserved by university libraries in Northeastern Nigeria

Design/Methodology/Approach - Quantitative research method was adopted for the study. Five heads of ICT/Media departments/units/divisions, representing 1 from each of the University Libraries were selected and served as subjects of the study.

Findings - The findings showed that theses, dissertation, multimedia and audio-visual materials, post print journal articles, book sections and chapters were the major electronics local content found in the University Libraries in North East while pre-print journal articles, unpublished reports, working papers, datasets, content package learning objects, software and patent were totally lacking. Refreshing, normalization and migration were found to be the most preservation strategies used in the libraries.

Originality/Value - This paper provides direct evidence on how digital local content are been preserved by university libraries in Northeastern Nigeria, it revealed Digital Local Content available and their preservation strategies.

Keywords: Management, Local Content, Electronic Local Content, Northeast Nigeria

Received: 10 September 2018, Revised 21 December 2018, Accepted 13 January 2019

(C) 2019 DLINE. All Rights Reserved

DOI: $10.6025 /$ ijwa/2019/11/2/65-70

\section{Introduction}

Universities are comprised of teachers and students who come together to pursue excellent academic knowledge and researches. Iwe (2010) asserts that a university is a research engine of the society, situated in cities but not really part of them. The people in 
them are immensely talented, rigorously intelligent, indulging in activities above the daily pursuits of the ordinary people. This community is consisting of professors, doctorial scholars, men and women pursuing mastery over various specific subject fields, together with youths and teenagers undertaking the basic fundamentals of knowledge in diverse fields of learning. This same community, as a result of its broad focus in teaching, research and learning, create knowledge and vital information that are useful to humanity. Most importantly, the knowledge and information created by members of this community are compatible with the culture of the people.According to Abdul (2010) local content is an expression and communication of a community's locally generated, owned and adapted knowledge and experience that is relevant to the community's situation. Bhattacharjee (2001) asserts that local content of a nation is generally defined as a work which is produced under the creative control of nationals of a country. Meanwhile, the economist definition of local content is that it is the proportion of input which comes from the country itself, as opposed to those imported. Furthermore, Local content is the totality of the culture, values, heritage materials, and indigenous knowledge of a group of people with common interest in a given locality. Ballantyne (2002) also viewed local content as what a community creates, owns, or adapts in terms of knowledge. It is a vital platform for local people to express, share, and communicate locally-relevant knowledge on the issues that affect their lives. Mutula (2007) posits that local content could be referred to as locally-owned, locally adapted, produced, or published content.

Olmeda-Gómez, et al (2008) notes that universities are generators of scholarly knowledge, they publicise the results of their research in globally open articles, using the channels afforded by existing journals to share their findings as widely as possible with different communities and audiences.

According to Chimezie (2012) Local content found in a university community are primarily borne out of scholarly research. In Nigeria, few universities focus on subject areas like agriculture, technology, education, while majority are conventional, teaching a vast range of knowledge. Some of the local content originating from university communities includes;

- Books

- Thesis and Dissertations

- Practical Research Records

- Journal Articles

- Project Reports

- Inaugural Lecture Recordings and Papers

- Evaluation Reports

- Technical Reports

- Workshop Reports

-Working Papers

- Conference Papers

- Conference Proceedings

- Field Trip Films And Records

- Inventions

- Records of community services of academics

This content is not only in text form but include speech recordings in cassettes and other digital resources.

\section{Concerns for Preservation of Digital Local Content in Libraries}

The current transition into a new information age presents a new set of concerns with the proliferation of electronic local contents in academic institutions across the globe. Digital preservation, or the archiving of electronic resources emanating in Nigerian Universities for preservation and access, is an issue that must be resolved to ensure the retention of human heritage in perpetuity.

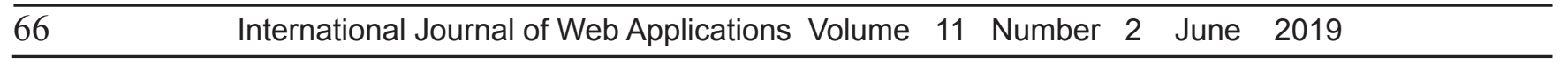


Digital preservation of local content requires active management and continuous vigilance to retain digital objects and their meaning (Lynch, 2003; Poynder, 2003, Russell, 2002). Unlike traditional preservation methods employed in libraries and archives, records for electronic objects must be maintained continually due to rapid changes in the current digital environment. Marcum and Friedlander (2003) assert that "archiving must be considered at the time the material is created rather than at the end of the distribution chain," which is opposite of the traditional book and paper preservation practice in which preservation is considered only after the material has been acquired for access.

With the advent of the Internet and desktop publishing phenomena, more material is being produced. And as individuals who were once patrons of the library now create and publish their own material, libraries are faced with another issue in archiving digital information not only from traditional publishers but from individuals as well. In general, the creator of digital resources is neither concerned nor invested in long-term preservation of their materials initially (Smith, 2003). Further, Lynch (2003) goes on to describe libraries as a secondary market for digital information with little control over the creation, proliferation, and accessibility of digital resources.

As a result, the onus falls on libraries, publishers, and other scholarly communication entities to resolve tension and document humanity in a manner that serves both posterity and scholarship. Jeff Rothenberg, a prominent researcher in digital preservation, outlines other guiding factors involved in digital preservation activities: first, the resource should be able to be copied perfectly; second, individuals should have access to materials without respect to geographic location; third, information should be machine-readable; and fourth, the process should preserve the unique functionality of the original item (Teper and Kraemer, 2002). With these factors - a lack of knowledge of preservation issues and the resource-intensive, proactive nature of digital preservation - libraries and information professionals face a difficult task.

Digitisation and preservation of priceless and valuable local content collection of an institution can bring prestige the institution; it will create visibility not only to the institutional content but also the scholar's work within the institution and raise the profile of the institution by showcasing its digital collections which can be useful for public relation exercise (Mckay, 2003; Ezaeni and Ezema, 2009).

\section{Objective of the Study}

The specific objectives are:

1. To determine the types of Digital Local Content available in the University Libraries studied

2. To determine the preservation strategy or combination of strategies used by the Libraries under Study

\section{Methodology}

Quantitative research method was adopted for the study. The population for the study is made up of all university libraries in Northeastern Geopolitical zone of Nigeria. Combinations of sampling techniques were used for this study. Firstly, judgment or purposive sampling technique was used to draw the population from the University Libraries in Northeast Nigeria. Using the method, a sample of five university libraries was selected and used. The choice of this sampling technique was as result of the fact that the researchers used the university libraries with functional ICT/Media division and runs postgraduate courses. Five heads of ICT/Media departments/units/divisions, representing 1 from each of the University Libraries selected are the subjects of the study. The instrument used to collect data for this study was semi-structured questionnaire. The researchers administered the questionnaires personally without any research assistant to all the respondents, this is because the researchers intends to strictly guide the respondents because of the some technical terms that exist in the questionnaires to avoid any misinformation and subsequent jeopardy of the research work. All the questionnaires distributed were successfully returned.

\section{Types of Digital Local Content Available in the University libraries Studied}

One of the objectives of this research is to determine the type of digital local content available for the establishment of Institutional Digital Repository among libraries in Northeastern Nigeria. In order to achieve this objective, the researcher first attempted to identify the digital local content available in libraries under study. To do this, a list of digital local contentwas provided for the respondents to tick as many as applicable to the libraries studied. This is shown in table 1 below. 


\begin{tabular}{|l|c|c|c|c|c|}
\hline Digital Local Content & $\begin{array}{l}\text { ADSU } \\
\text { Library }\end{array}$ & $\begin{array}{l}\text { ATBU } \\
\text { Library }\end{array}$ & $\begin{array}{l}\text { GSU } \\
\text { Library }\end{array}$ & $\begin{array}{c}\text { BB Library, } \\
\text { MAUTECH }\end{array}$ & $\begin{array}{c}\text { Ramat Library, } \\
\text { UNIMAID }\end{array}$ \\
\hline Pre-print Journal articles & $\mathrm{X}$ & $\mathrm{X}$ & $\mathrm{X}$ & $\mathrm{X}$ & $\mathrm{X}$ \\
\hline Post-print journal articles & $\mathrm{X}$ & $\mathrm{X}$ & $\sqrt{ }$ & $\sqrt{ }$ & $\sqrt{ }$ \\
\hline Books, sections and chapters & $\mathrm{X}$ & $\sqrt{ }$ & $\mathrm{X}$ & $\sqrt{ }$ & $\sqrt{ }$ \\
\hline Conference and workshop papers & $\sqrt{ }$ & $\mathrm{X}$ & $\mathrm{X}$ & $\mathrm{X}$ & $\mathrm{X}$ \\
\hline $\begin{array}{l}\text { Theses and Dissertations } \\
\text { Unpublished reports \& }\end{array}$ & $\sqrt{ }$ & $\sqrt{ }$ & $\mathrm{X}$ & $\sqrt{ }$ & $\mathrm{X}$ \\
\hline working papers & $\mathrm{X}$ & $\mathrm{X}$ & $\mathrm{X}$ & $\mathrm{X}$ & $\mathrm{X}$ \\
\hline Datasets & $\mathrm{X}$ & $\mathrm{X}$ & $\mathrm{X}$ & $\mathrm{X}$ & $\mathrm{X}$ \\
\hline $\begin{array}{l}\text { Content packaged learning } \\
\text { objects }\end{array}$ & $\mathrm{X}$ & $\mathrm{X}$ & $\mathrm{X}$ & $\mathrm{X}$ & $\mathrm{X}$ \\
\hline $\begin{array}{l}\text { Multimedia and audio visual } \\
\text { materials }\end{array}$ & $\sqrt{ }$ & $\sqrt{ }$ & $\sqrt{ }$ & $\sqrt{ }$ & $\sqrt{ }$ \\
\hline $\begin{array}{l}\text { Software } \\
\text { Patents }\end{array}$ & $\mathrm{X}$ & $\mathrm{X}$ & $\mathrm{X}$ & $\mathrm{X}$ & $\mathrm{X}$ \\
\hline
\end{tabular}

Key: $X=$ Not Applicable $\sqrt{ }=$ Applicable

Table 1. Types of Digital Local Content Available in the University Libraries

Table above shows that only multimedia and audio visual materials are found in all the libraries studied while none of the libraries have pre-print journal articles, unpublished reports \& working papers, content packaged learning objects, software and patents. However, only ADSU library reported availability of conference and workshop papers. This poor availability of digital local content may not be unconnected with lack of digitisation efforts of local content in Nigerian university libraries despite its importance as reported by Mckay (2003), Ezaeni and Ezema (2009) who asserted that digitisation of priceless and valuable collection of an institution can bring prestige to the institution; it will create visibility not only to the institutional local content but also the scholar's work within the institution and raise the profile of the institution by showcasing its digital collections which can be useful for public relation exercise.

\section{Preservation Strategy or Combination of Strategies Used by Libraries under Study for Management of Digital Local Content}

Electronic local content preservation strategies are methods used for keeping stored digital objects permanently accessible for long-term re-use. The strategies adopted by libraries studied depend largely on the file format used and infrastructures available. However, more than one strategy can be adopted by libraries. The researcher sought to find out the strategies adopted by the libraries studied. The findings were captured in Table below

Table 2 shows that refreshing, normalization and migration are the only digital preservation activities carried out for the management of electronic local content while none uses any of emulation, encapsulation, universal virtual computer, LOCKSS, open 


\begin{tabular}{|c|c|c|c|c|c|}
\hline Preservation Strategies & ADSU Library & ATBU Library & GSU Library & $\begin{array}{l}\text { IBB Library, } \\
\text { MAUTECH }\end{array}$ & $\begin{array}{l}\text { Ramat } \\
\text { Library, } \\
\text { UNIMAID }\end{array}$ \\
\hline Refreshing & $\sqrt{ }$ & $\sqrt{ }$ & $\sqrt{ }$ & $\sqrt{ }$ & $\sqrt{ }$ \\
\hline Technology preservation & $\mathrm{X}$ & $\mathrm{X}$ & $\mathrm{X}$ & $\mathrm{X}$ & $\sqrt{ }$ \\
\hline Normalization & $\sqrt{ }$ & $\sqrt{ }$ & $\sqrt{ }$ & $\sqrt{ }$ & $\sqrt{ }$ \\
\hline Migration & $\mathrm{V}$ & $\mathrm{X}$ & $\mathrm{X}$ & $\mathrm{X}$ & $\mathrm{X}$ \\
\hline Emulation & $\mathrm{X}$ & $\mathrm{X}$ & $\mathrm{X}$ & $\mathrm{X}$ & $\mathrm{X}$ \\
\hline Encapsulation & $\mathrm{X}$ & $\mathrm{X}$ & $\mathrm{X}$ & $\mathrm{X}$ & $\mathrm{X}$ \\
\hline Universal Virtual Computer & $\mathrm{X}$ & $\mathrm{X}$ & $\mathrm{X}$ & $\mathrm{X}$ & $\mathrm{X}$ \\
\hline LOCKSS & & & & & \\
\hline
\end{tabular}

Key: $X=$ Not Applicable $\sqrt{ }=$ Applicable

Table 2. Preservation Strategy or Combination of Strategies Used by Libraries for Management of Digital Local Content

archival information system (OAIS) and technology preservation in libraries in northeastern Nigeria. The table further reveals the poor exploitation of the most digital preservation strategies, which further puts the digital local contents in these libraries at risk of lost.

\section{Summary of Findings}

Based on the data collected and analysed for this study, the following are the major findings of the study

1. Theses and dissertations, multimedia and audio visual materials, post-print journal articles, books sections and chapters are the major electronic local contents available in the university libraries in northeastern Nigeria while pre-print journal articles, unpublished reports \& working papers, datasets, content packaged learning objects, software and patents are totally lacking.

2. Refreshing, normalization and migration are found to be the most preservation strategies used in the libraries in northeast Nigeria.

\section{Conclusion}

The world is going digital at an astounding rate. The scholarly community, like the general public, is moving rapidly into this digital environment, and the digital scholarly content being created today in universities must be preserved for the future, without guaranteed access to this record over the very long term, future research will be hampered. Traditional preservation responsibilities and methodologies are not applicable to digital content, where physical copies are not delivered to libraries. Instead, in order to meet the unique preservation needs of digital content, libraries as key participants in the scholarly communications environment must invest in a qualified archiving solution.

\section{References}

[1] Abdul, K. (2010). Promoting Local Content. A Paper Presented at World Submit on the Information Society. Paris, France. 
Retrieved April 18, 2013 from http://www.itu.int/wsis/docs/pc2/roundtables/rt2/khan.pdf.

[2] Ballantyne, C. W. (2002). Open Access Bibliography: Liberating Scholarly Literature with E-prints and Open Access Journals: Association of Research Libraries Washington, DC.

[3] Bhattacharjee, K. (2001). Local Content Rules in Broadcasting. A Legal Document.Article 19. March 2001. Canada. Accessed on April 23, 2013 from http://www.article19.org/pdfs/publications/local-content-rules.pdf.

[4] Borghoff, et al. (2006). Long-Term Preservation of Digital Document: Principles and Practices. Springer-Verlag Berlin Heidelberg.

[5] Chimezie, P. U. (2012). The Role of University Libraries in Enhancing Local Content Availabilityin the Nigerian Community.Library Philosophy and Practice. Accessed on April 23, 2013 from http://www.webpages.uidaho.edu/ mbolin/ uzuegbu.htm.

[6] Ezeani, C. N., Ezema, I.J. (2009). Digital Preservation of the Cultural Heritage of University of Nigeria Nsukka: Issues and Current Status. In: Libraries Create Futures: Building on Cultural Heritage. Papers Presented at the $47^{\text {th }}$ National Conference and Annual General Meeting of the Nigeria Library Association.

[7] Iwe, M. O. (2010). The Role of Students in Sustaining University Culture. A Paper Presented at the Maiden Workshop on University Culture held on Friday March 12, 2010 at the Prof. Chinua Achebe Lecture Theatre. Michael Okpara University of Agriculture, Umudike, Abia State.

[8] Lynch, C. A. (2003). The coming crisis in preserving our digital cultural heritage. Journal of Library Administration, 38 (3/4) $149-161$.

[9] Marcum, D.B., Friedlander, A. (2003). Keepers of the crumbling culture: What digital preservation can learn from library history. D-Lib Magazine, 9 (5) Retrieved October 26, 2016, from http://www.dlib.org/dlib/may03/friedlander/05friedlander.html.

[10] McKay, S. (2003). Digitization in an Archival Environment. Electronic Journal of Academic and Special Librarianship 4 (1).

[11] Mutula, S.M. (2008). Local content and Africa's presence on the Web.In Aina, L.O. (Ed.).information and knowledge management in the digital age: Concepts, technologies, and African perspectives. Ibadan:Third World Information Service, $p$. 56.

[12] Olmeda-Gómez, C., Perianes-Rodríguez, A., Ovalle-Perandones, M.A., Moya-Anegón, F. (2008). Comparative Analysis of University Government-Enterprise Co-authorship Networks in three Scientific Domains in the Region of Madrid, 19952003.Information Research, 13(3) paper 352.Accessed on April 22, 2013 from http://InformationR.net/ir/13-3/paper352.html.

[13] Poynder, R. (2003). Elephants and dung trucks. Information Today, 20 (8) 33- 34, 36.

[14] Russell, K. (2002). Libraries and digital preservation: Who is providing electronic access for tomorrow? In: Charles F. Dekker (Ed) Libraries, the Internet, and Scholarship (pp. 1-30). New York: Marcel Dekker, Inc.

[15] Smith, A. (2003). New-Model scholarship: Headed for early obsolescence? Retrieved January 28, 2016, from http://www.clir.org/ pubs/reports/pub114/newmod.html.

[16] Teper, T.H. Kraemer, B. (2002). Long-term retention of electronic theses and dissertations. College and Research Libraries, 63 (1) 61-72. 